\title{
Jakim językiem zapraszać na konsultacje społeczne? [komunikat]*
}

Tuż po studiach humanistycznych w swojej pierwszej poważnej pracy prowadziłam stronę internetową. Pisałam aktualności o wydarzeniach w programie unijnym. Żeby zebrać materiały, czytałam, co piszą moi koledzy i koleżanki z departamentu. Czytałam i dziwiłam się. Język był tak niezrozumiały, że trudno mi było sobie wyobrazić, że służy komunikacji. Ale potrafili tak pisać - miałam wrażenie - wszyscy oprócz mnie.

Któregoś dnia moja szefowa przyszła do mnie i dała mi książkę. „Wydało nasze ministerstwo. Przeczytaj, przyda ci się”. Książka nazywała się Jak pisać o Funduszach Europejskich, jej autorami byli Jan Miodek, Marek Maziarz, Tomasz Piekot, Marcin Poprawa i Grzegorz Zarzeczny. Czytałam i czułam ulgę. Miałam szczęście. Dostałam instrukcję jak można poprawić ten język i argumenty dlaczego trzeba to robić.

Ta książka to pierwsza w Polsce planowa próba uproszczenia języka urzędowego. Ministerstwo Rozwoju Regionalnego wydało ją w 2010 roku. Jej autorzy, językoznawcy, stworzyli później Pracownię Prostej Polszczyzny.

Teraz pracuję w Urzędzie Miasta Stołecznego Warszawy, w Centrum Komunikacji Społecznej. Mój wydział pomaga urzędnikom i urzędniczkom merytorycznym zaplanować konsultacje społeczne. Pomagamy też pisać ogłoszenia, plakaty i inne materiały.

\section{Komunikacja konsultacji społecznych}

W 2017 roku wiedzieliśmy, że potrzebujemy zmiany symboli wizualnych, które stosujemy, kiedy mówimy o konsultacjach. Ta identyfikacja wizualna, którą się posłu-

\footnotetext{
* Artykuł powstał na podstawie tekstu, który przygotowałam do książki o dobrych praktykach w konsultacjach. Książka ta, wydana przez Centrum Komunikacji Społecznej Urzędu Miasta Stołecznego Warszawy, dostępna jest pod adresem: https://konsultacje.um.warszawa.pl/24_inspiracje_z_warszawy (dostęp: 1.04.2021).
} 
giwaliśmy, była przestarzała. Przy okazji postanowiliśmy przyjrzeć się całej komunikacji o konsultacjach — także językowi, który stosujemy w materiałach. Chcieliśmy znaleźć odpowiedzi na pytanie: jak nasze ogłoszenia i plakaty o konsultacjach mogą zachęcić ludzi do udziału w konsultacjach?

W tej refleksji pomagała nam firma zewnętrzna. Pracowaliśmy z nią od listopada 2017 do kwietnia 2018 roku. Braliśmy udział kilka razy w warsztatach. Na bieżąco czytaliśmy i komentowaliśmy powstające materiały. Zaczęliśmy od badań.

Okazało się, że ludzie często nie biorą udziału w konsultacjach, bo uważają, że:

- decyzja już zapadła, a konsultacje to tylko przykrywka, więc nie ma sensu w nich brać udziału,

- konsultacje społeczne są nie dla nich, mogą w nich brać udział tylko eksperci,

- istnieją „oni” - urzędnicy, którzy mają władzę, którzy są wrodzy wobec mieszkańców i raczej nie warto z nimi rozmawiać,

- konsultacje to próba sił, a nie wymiana opinii; są tu wygrani i przegrani, wygrywa ten, kto głośniej krzyczy.

To są przekonania, które zniechęcają ludzi do współdecydowania o mieście. Wiemy, że biorą się one z różnych źródeł i na wiele z nich nie mamy wpływu. W pewnym stopniu możemy jednak te obawy zniwelować komunikacją — albo je pogłębić.

$\mathrm{Na}$ podstawie badań powstał pomocnik „Jak informować o konsultacjach społecznych". Ważną jego częścią okazał się język, o którym piszę w tym artykule. Na koniec powstała nowa identyfikacja wizualna warszawskich konsultacji.

Najwięcej o języku dowiedzieliśmy się z badań w formie fokusów i z analizy semiotycznej. Analiza semiotyczna to badanie tego, co znaczą słowa i sformułowania w kontekście kulturowym, w którym występują. W ten sposób badaliśmy nasze komunikaty wizualne i język - słowa i sformułowania. Taka analiza pomogła nam uporządkować wiele naszych dobrych praktyk.

\section{Dbamy o relacje $w$ tekście}

Dzięki analizie semiotycznej przypomnieliśmy sobie, że urząd to miejsce, w które mało kto chodzi dla przyjemności. Ludzie często nie ufają urzędnikom i wierzą, że ci wynoszą się nad innych. Urząd i urzędnicy to „oni”. Dlatego w naszych ogłoszeniach o konsultacjach powinniśmy budować takie relacje z odbiorcą, by można było nam łatwiej zaufać.

W związku z tym przyjęliśmy ogólną wskazówkę:

W konsultacjach wszyscy są równi, dlatego zapraszając do rozmowy, niwelujemy barierę urzędnicy-warszawiacy, a przede wszystkim nikogo i niczego nie wyróżniamy (zwłaszcza jeśli chodzi o urząd).

W praktyce określiliśmy trzy językowe zasady: unikamy podziału na my-wy, ujawniamy siebie, zwracamy się do odbiorców. 


\section{Unikamy opozycji my-wy}

Staramy się nie pisać zdań, w których my (urząd) wyrażamy swoje oczekiwania wobec mieszkańców i stawiamy siebie poza tą grupą. Na przykład takich:

- będziemy chcieli z Wami porozmawiać (urząd dyktuje warunki),

- czekamy na Twoje pomysty (urząd poczeka, a ty się postaraj)

Jeśli tylko się da, używamy inkluzywnego „my”. To forma, która włącza i przedstawicieli urzędu, i mieszkańców:

- spotkajmy się,

- porozmawiajmy.

\section{Ujawniamy siebie}

Czasami „my” musi oznaczać urząd. Stosujemy wtedy czasowniki w stronie czynnej, w pierwszej osobie liczby mnogiej. Nie ukrywamy się za formami biernymi czy bezosobowymi. Piszemy na przykład tak:

- przeanalizowaliśmy opinie,

- wyremontujemy wille przy Siarczanej,

zamiast:

- przeanalizowano uwagi,

- willa przy Siarczanej będzie remontowana.

Uważamy też, by nie używać nazw poszczególnych działów i jednostek miasta. Mówimy jako Warszawa - jedno miasto. A zatem wyremontujemy park, a nie Zarząd Remontów Parków wyremontuje park.

\section{Zwracamy się do odbiorców}

Do odbiorców zwracamy się bezpośrednio - per „Ty” albo „Wy”. Nie stosujemy zwrotu grzecznościowego „Państwo” w ogłoszeniach o konsultacjach. To zwiększałoby dystans i sugerowało, że sytuacja jest oficjalna.

Pisanie per „Ty” to zwykła praktyka w tekstach w internecie. Zdarza się jednak, że urzędnicy, z którymi pracujemy, nie chcą zrezygnować ze zwrotów grzecznościowych „Państwo”. Sądzą oni, że lepiej wyrażają one szacunek. Tymczasem szanujemy czytelnika wtedy, kiedy piszemy prosto i zrozumiale.

Nie piszemy zatem:

- Chcemy poznać Państwa opinie,

- Od Państwa zależy, 
tylko:

- Twoja opinia się liczy,

- Od Ciebie zależy.

Nie piszemy też o odbiorcach w trzeciej osobie. Unikamy zdań typu:

- zapraszamy mieszkańców do wzięcia udziału w konsultacjach społecznych (zapraszamy jakichś mieszkańców, ale nie ciebie, czytelniku),

- chcemy zaprezentować projekty przyszłym użytkownikom i spytać ich o zdanie (to zdanie mówimy do przyszłych użytkowników - czy jednak ktoś z przyszłości przeczyta nasz plakat?).

Najważniejszym sposobem dbania o relacje w tekście jest też pisanie tego, co odbiorcy jest potrzebne. Dlatego pisząc o konsultacjach, przekazujemy informacje z punktu widzenia ludzi, a nie urzędu. Piszemy raczej tak:

Twoja okolica się zmieni. Już w przyszłym roku przebudujemy skwer przy ulicy Kwiatowej. Powiedz, co ma zostać jak jest, a co powinno się zmienić,

niż tak:

Urząd Miasta rozpoczą projekt, który zakłada przebudowę 20 skwerów w całym mieście, m.in. skweru przy Kwiatowej. Pragniemy, by była to przestrzeń przyjazna dla mieszkańców i odpowiadająca na ich potrzeby.

Tyle analiza semiotyczna. Ale nasze badania miały też inne składniki. Na wiele konkretnych rozwiązań wpadliśmy dzięki fokusom.

Zogniskowany wywiad grupowy, popularnie zwany fokusem, to metoda opierająca się na sytuacji, w której badacz rozmawia przy stole z kilkoma osobami. Są to ludzie dobrani ze względu na swoje cechy — na przykład wiek, doświadczenie. W naszym przypadku tematem rozmowy były plakaty informujące o konsultacjach, wpisy na Facebooku i komunikaty ze strony internetowej. Rozmawiały o nich cztery grupy:

- osoby, które nigdy nie brały udziału w konsultacjach, ale są zainteresowane miastem (dwie grupy: 25-35 lat i 40-55 lat);

- osoby, które w konsultacjach uczestniczyły, również w podziale na grupę młodszych i starszych dorosłych.

Badaczka i grupa siedziały przy stole w pokoju, który zamiast jednej ze ścian miał lustro weneckie. My siedziałyśmy zaś za lustrem i słuchałyśmy, jak uczestnicy i uczestniczki komentują nasze materiały. Nie zawsze były to życzliwe komentarze. Dowiedziałyśmy się, że dotychczas popełniano kilka błędów.

\section{Wezwania do działania}

Dotychczas zapraszano na konsultacje na przykład tak:

Dowiedz się więcej o zmianach, odwiedź www.xxx.pl!

Zgłoś uwagi mailemna xxx@um.warszawa.pl do 23 listopada 2017 r.

Przyjdź na spotkanie" [wyróżnienia: MP]. 
Panowało przekonanie, że im więcej dajemy możliwości działania (możesz wysłać e-mail, możesz przyjść na jedno z wielu spotkań w różnych częściach miasta, możesz przyjść na warsztaty i wspólnie zastanowić się nad rozwiązaniami), tym lepiej. Kiedy powiemy naszym odbiorcom o wszystkich możliwościach, ci wybiorą najlepszą dla siebie opcję. Wyobrażamy sobie, że w ten sposób skutecznie wzywamy do działania, a nasz komunikat jest dynamiczny i angażujący.

Tymczasem uczestnicy fokusów patrzyli zdziwieni na ten tekst. Niektórzy nie rozumieli, które z tych rozkazów mają wykonać. Czy żeby wziąć udział w konsultacjach, trzeba zrobić to wszystko: i przeczytać na stronie, i napisać e-mail, i przyjść na spotkania?

Wyciągnęliśmy z tego wniosek, że choć tryb rozkazujący angażuje, to gdy stosujemy go w nadmiarze, zaczyna być odbierany jako próba zmuszenia do działania. Ludzie bywają zmęczeni nadmiarem dróg do wyboru i w efekcie mogą odrzucić je wszystkie. Język powinien być konkretny, nienachalny, bez wykrzykników. Zdecydowaliśmy, że dopuszczamy maksymalnie dwa wezwania do działania w jednym komunikacie. Zapisaliśmy: „Łatwiej spełnić jedną prośbę niż dziesięć, dlatego minimalizujemy liczbę wezwań do działania (na przykład Wypełnij ankietę!, Weź udział!, Powiedz!), które powinny być wyraźne, ale nie nachalne”.

\section{Pytamy o potrzeby czy pomysły}

W dotychczasowych materiałach czasem prosiliśmy: Podziel się pomysłem, Czekamy na Twoje pomysły. W czasie badań dowiedzieliśmy się, że pytanie o pomysły onieśmiela. Nie każdy czuje się tak pewny swoich pomysłów, by wypowiedzieć je na głos. Nie każdy je w ogóle ma. Każdy ma za to potrzeby i wiedzę o swojej okolicy.

Zdecydowaliśmy więc, że będziemy unikać słowa „pomysły”. W pomocniku zapisaliśmy:

Chcemy znać punkty widzenia i potrzeby, a nie wielkie idee, dlatego pytamy wprost o opinie ludzi, zamiast liczyć na gotowe, przełomowe pomysły — pytanie o nie może onieśmielać (nie mówimy więc np. „podziel się pomysłem”).

We wskazówkach językowych zalecamy „,konkretne pytania o potrzeby lub samopoczucie, a nie o pomysły lub rozwiązania”. Proponujemy, by pisać na przykład tak:

- Powiedz, czego Ci brakuje

- Jak czujesz się w okolicy?

- Co chcesz tu robić? 


\section{Unikamy żargonu}

Od dawna unikaliśmy specjalistycznego języka w tekstach o konsultacjach. Staraliśmy się usuwać z naszych materiałów słowa, które mogłyby się wydawać niezrozumiałe. Często się udawało. Autorom tekstów wyjaśnialiśmy, że ludzie nie spacerują po „wnętrzach ulicznych” pod „dojrzałym drzewostanem”, raczej chodzą po ulicach i korzystają z cienia drzew. Język, którym mówią między sobą specjaliści z danej branży, w komunikacji z mieszkańcami jest nieskuteczny, bo buduje dystans między nadawcą i odbiorcą. Sugeruje, że temat konsultacji jest specjalistyczny i że mogą wypowiedzieć się tylko eksperci. Takie wyjaśnienie często przekonywało autorów.

Dziwiło więc nas, kiedy na fokusach ludzie zaczęli wyłapywać urzędowe i żargonowe wtręty w naszych tekstach. Okazało się, że za często przeoczamy słowa związane z partycypacją.

Pierwszy przykład to słowo „warsztaty”. Osoba w wieku 40-55, która nigdy nie brała udziału w konsultacjach, powiedziała o nich: „Część ludzi nie wiedziałaby, o co chodzi w tym haśle "przyjdź na warsztat«. Kojarzy się z warsztatem samochodowym". Inni kojarzyli warsztaty z zajęciami dla dzieci. Albo myśleli, że będą się na nich czegoś uczyć.

Inne przykłady: spacer badawczy niektórym kojarzył się z badaniami medycznymi, debata z rozmową polityków, w której nie ma miejsca na głos mieszkańców, dyżur projektanta zaś ze szkołą i z niewygodą — nauczycielka wyznacza termin, do którego trzeba się dopasować.

Tymi słowami my, organizujący dialog publiczny, posługujemy się na co dzień w pracy. Pomagają nam opisywać różne formy spotkań i rozmów. Nie dostrzegaliśmy, że można ich nie rozumieć. Dlatego nazwaliśmy to ślepą plamką. Ślepa plamka jest niezbędna, by oko widziało, a jednak sama utrudnia widzenie centrum obrazu.

W pomocniku zalecamy więc stosowanie "prosto opisanych form konsultacji zamiast nazw narzędzi (jeśli wyjątkowo musisz podać specjalistyczny termin, to wyjaśnij jego znaczenie)". Przykłady: spotkanie otwierające można zamienić na spotkanie; warsztat kreatywny - na spotkanie i wspólne planowanie przestrzeni; interakcyjno-animacyjny punkt konsultacyjny - na punkt konsultacyjny.

Dlaczego? Ponieważ - cytując pomocnik:

Wszyscy są zalatani, dlatego pokazujemy konsultacje społeczne jako coś prostego, logicznego i nieczasochłonnego: nie używamy specyficznych słów niezrozumiałych dla przeciętnego warszawiaka.

Komunikaty kierujemy do szerokiej grupy odbiorców — specjalistyczne słownictwo nie buduje poczucia profesjonalizmu, tylko alienuje potencjalnych odbiorców.

Jak również:

Nikt nie lubi biurokracji, dlatego staramy się unikać wszystkiego, co kojarzy się z długimi, skomplikowanymi urzędniczymi sprawami. Eliminujemy elementy żargonu urzędniczego [...]. 


\section{Stosujemy lokalne nazwy własne}

Dotychczas w konsultacjach staraliśmy się unikać oficjalnych nazw miejsc i stosować zwyczajowe. Nie zawsze jednak było łatwo przekonać. Urzędnicy i wykonawcy konsultacji często chcieli, by na plakacie umieścić nazwę oficjalną, bo ta brzmi poważniej.

Badania potwierdziły, że trzeba opisywać miejsca tak, jak mówią ludzie, a nie tak, jak nazywają je dokumenty. Jeśli używamy potocznej nazwy, to odbiorca czuje, że mówimy tym samym językiem co on. Lepiej więc pisać o parku Dreszera, a nie o parku gen. Gustawa Orlicz-Dreszera. Ale to nie tylko kwestia stylu. Czasem użycie nazwy oficjalnej może sprawić, że odbiorca nie zrozumie, o jakim miejscu mowa. Tak jest w przypadku parku im. Cichociemnych Spadochroniarzy AK, który większość mieszkańców zna jako Górkę Kazurkę.

W pomocniku zapisaliśmy:

Każdy z nas gdzieś przynależy, dlatego staramy się zaznaczyć lokalny charakter tematów konsultacji, odwołując się do popularnych nazw miejsc, budynków itp., zwłaszcza w nagłówkach komunikatów.

Także nazwy miejsc, w których odbywają się spotkania, zapisujemy zgodnie z potocznym zwyczajem. Piszemy więc Szkoła Podstawowa nr 211, a nie Szkoła Podstawowa $n r 211$ z Oddziałami Integracyjnymi im. J. Korczaka. Na plakatach, które muszą być zwięzłe, nie podajemy też adresów, jeśli są oczywiste (na przykład adres centrum kultury czy urzędu dzielnicy). Dzięki temu unikamy też wodolejstwa, które kojarzy się z urzędami.

\section{Unikamy gier słownych}

Każde konsultacje mają swój tytuł. Wiele naszych miało formę prostego pytania ( $\mathrm{Ja}$ kie Pole Mokotowskie?, Jakie ulice Nowej Pragi?). Niektóre były zachętą do wspólnego działania (Ulepszmy plac Hallera).

Zdarzały się jednak tytuły metaforyczne: $Z$ jaka obwodnica będzie nam po drodze? (konsultacje o obwodnicy), Wyrzuć to do właściwego kosza (konsultacje nowego systemu segregacji śmieci). Miały one intrygować i sprawiać, że czytelnik przeczyta coś więcej niż tytuł. W rzeczywistości wielu uczestników badań fokusowych nie chciało, żeby urząd próbował przykuć ich uwagę fikuśnym stylem. Oczekiwali prostych, informacyjnych tytułów.

To zrozumiałe. Konsultacje są często informacją o planowanej zmianie. Gdy władza je zapowiada, to ludzie są zaniepokojeni, czasem źli. Nie jest to dobry moment, by używać gier słownych.

Najciekawszy przypadek, który omawiali uczestnicy fokusów, to plakat konsultacji uchwały krajobrazowej. Nazwa całych konsultacji i ich identyfikacja wizualna 
opierała się na zabawie językowej: ŁAD/NIEŁAD/ŁADNIE. Plakat wypełniał ciąg znaków: ładnieładnieładnieład..., zapisany bezszeryfowymi kapitalikami, czarną czcionką na białym tle (zob. ilustracja 1, ilustracja 2).

Niektórzy uczestnicy fokusów:

- czuli, że jest to materiał o charakterze artystycznym („to chyba wariacja na temat polskiej szkoły plakatu...", powiedział drwiąco jeden z uczestników),

- sądzili, że wydarzenia, na które zapraszamy, nie są dla nich, tylko dla osób rozumiejących ten typ artystycznego przekazu.

To, co zrozumieli, było niezgodne $\mathrm{z}$ intencją nadawcy. To miał być ładny, przykuwający uwagę plakat, a stworzył on atmosferę ekskluzywności. To niefortunne, bo na te konsultacje byli zaproszeni także drobni przedsiębiorcy. Uchwała krajobrazowa może wpłynąć na to, jakich reklam i szyldów będą mogli używać. Tymczasem właśnie tę grupę plakat mógł zniechęcać.

Dlatego w pomocniku zapisaliśmy:

nagłówki konsultacji [powinny być] krótkie, oddające temat konsultacji (forma „Jaki” lub motywująca do działania), bez gry słownej

oraz:

Tytuł konsultacji musi być krótki, konkretny i duży (widoczny z daleka). Jeśli odbiorca uzna, że jest to temat dla niego interesujący, przeczyta dalszą część plakatu.

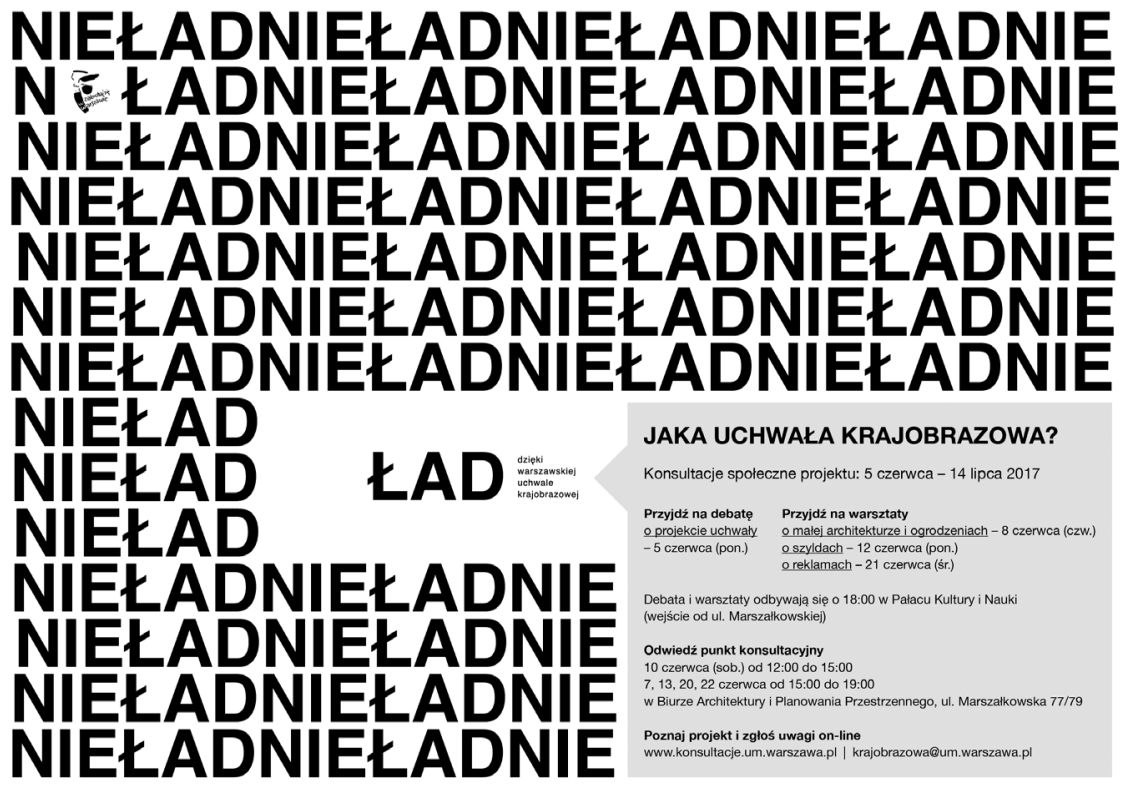

Ilustracja 1. Konsultacje uchwały krajobrazowej — afisz 


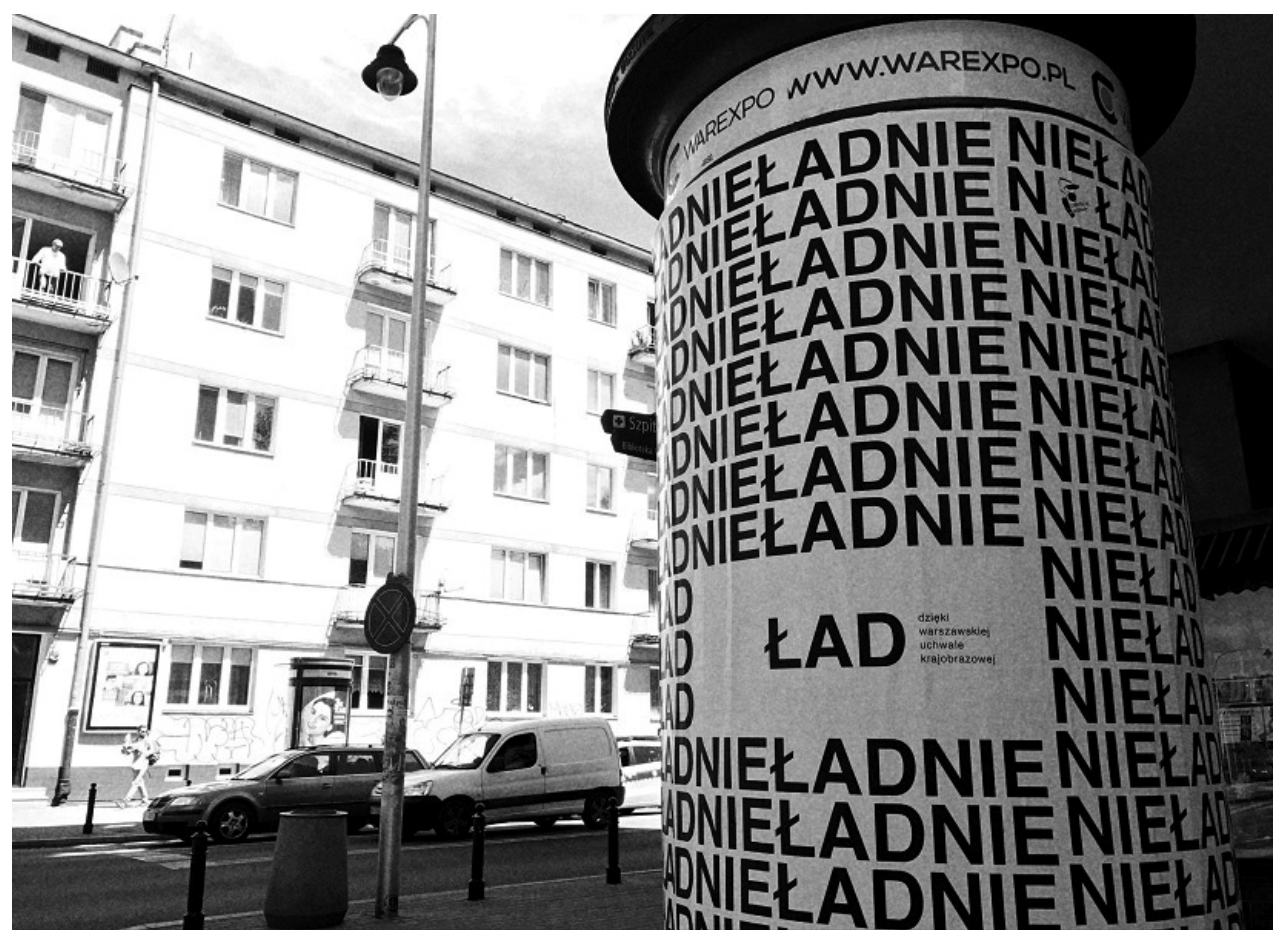

Ilustracja 2. Konsultacje uchwały krajobrazowej. Plakat na słupie ogłoszeniowym

\section{Unikamy urzędowej mowy}

Wiele powyższych wskazówek pozwala unikać urzędowego stylu. Pisałam o żargonie czy oficjalnych nazwach, które pojawiają się stosunkowo często. Inne błędy pojawiają się nieco rzadziej, ale warto też o nich przypomnieć. Odradzamy:

- używania strony biernej i form bezosobowych czasowników,

- formułowania długich lub wielokrotne złożonych zdań,

- wodolejstwa - nadmiaru słów.

Lepiej zatem nie pisać tak:

- Pierwotnie przewidywany termin nie mógł być dochowany (forma bezosobowa czasownika);

- Dyskusja publiczna nad przyjętymi w projekcie planu miejscowego rozwiązaniami odbędzie się [...] (długie zdanie, zbędne słowa);

- Chcemy, żeby godziła potrzeby lokalne z potrzebami komunikacyjnymi całej Warszawy. To dlatego pytamy Państwa o opinie na temat proponowanego projektu [...] (wodolejstwo);

tylko tak:

- Nie udało nam się dotrzymać terminu;

- Spotkanie o rozwiązaniach dla tej okolicy odbędzie się [...];

- Powiedz, co sadzisz [...]. 


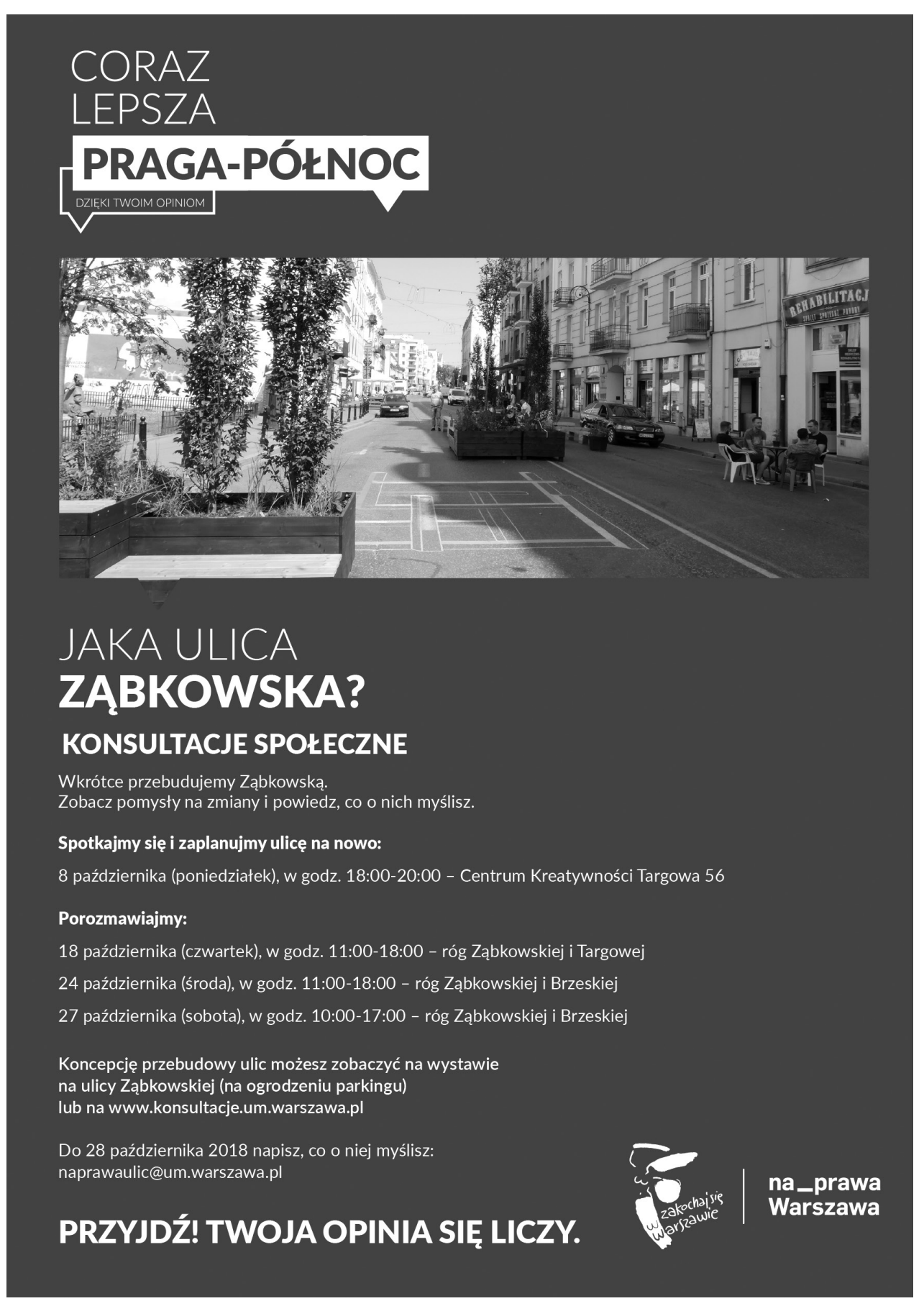

Ilustracja 3. „Jaka ulica Ząbkowska?”. Plakat konsultacji w nowej identyfikacji wizualnej 


\section{Wnioski}

Język, którym mówimy o konsultacjach, nie jest typowo urzędowy. Ma wiele naleciałości języka marketingowego. Autorki i autorzy muszą więc uważać na cechy obu tych stylów. Język marketingowy jest czasem podobny do prostego języka. Przykładowo, również dąży do prostoty. Jednakże relacje, które buduje w tekście, nie zawsze odpowiadają wartościom dobrej komunikacji społecznej - dialogowi, empatii czy otwartości. Dlatego też może przeszkadzać w komunikacji urzędu z mieszkańcami i mieszkankami.

Tym wartościom odpowiada prosty język. Krótkie, nieurzędowe sformułowania, proste słowa, pytania o potrzeby ułatwiają szybkie czytanie - ale nie tylko. Wyrażają też szacunek do czytelnika i tworzą warunki, by zaufać urzędowi. Wszystkie sposoby pisania, które zalecamy w naszym pomocniku, mają zachęcać ludzi, by zaangażowali się w sprawy miasta.

\section{Pomocnik Jak informować o konsultacjach społecznych? - dokument, który zawiera strategię komunikacji konsultacji społecznych.}

\section{Fragment: Język komunikacji. Ogólne wskazówki}

1. Nikt nie lubi biurokracji, dlatego staramy się unikać wszystkiego, co kojarzy się z długimi, skomplikowanymi urzędniczymi sprawami. Eliminujemy elementy żargonu urzędniczego, długie, wielokrotnie złożone zdania i stronę bierną [...].

2. Wszyscy są zalatani, dlatego pokazujemy konsultacje społeczne jako coś prostego, logicznego i nieczasochłonnego: nie używamy specyficznych słów niezrozumiałych dla przeciętnego warszawiaka, nie powtarzamy się.

3. Łatwiej spełnić jedną prośbę niż dziesięć, dlatego minimalizujemy liczbę wezwań do działania (np. Wypetnij ankietę!, Weź udział!, Powiedz!), które powinny być wyraźne, ale nie nachalne; podobnie z www — informujemy o jednym adresie strony internetowej, a nie dwóch.

4. W konsultacjach wszyscy są równi, dlatego zapraszając do rozmowy, niwelujemy barierę urzędnicy warszawiacy, a przede wszystkim nikogo i niczego nie wyróżniamy (zwłaszcza jeśli chodzi o urząd).

5. Każdy z nas gdzieś przynależy, dlatego staramy się zaznaczyć lokalny charakter tematów konsultacji, odwołując się do popularnych nazw miejsc, budynków itp., zwłaszcza w nagłówkach komunikatów.

6. Chcemy znać punkty widzenia i potrzeby, a nie wielkie idee, dlatego pytamy wprost o opinie ludzi, zamiast liczyć na gotowe, przełomowe pomysły — pytanie o nie może onieśmielać (nie mówimy więc np. podziel się pomysłem). 
7. Każdy słucha, gdy mówi się do niego bezpośrednio, dlatego piszemy do odbiorców w 2 osobie (Ty/Wy). Jeśli uczestnicy ewidentnie nie chcą łamać dystansu (np. są osobami starszymi lub czują, że konsultacje zagrażają ich interesom), możemy stosować formy grzecznościowe i zwracać się do nich Pan/Pani/Państwo.

8. Wodolejstwo jest męczące, a naszym celem nie jest zamęczanie ludzi. Jeśli jakieś słowa lub zdania wydają nam się zbędne, to zapewne takie są — pozbywajmy się ich w komunikacji. Zostawiamy w tekście tylko te zdania i słowa, które rzeczywiście są tam konieczne. 